(c) American Dairy Science Association, 2003.

\title{
Efficacy of Two lodine Teat Dips During Experimental Challenge with Staphylococcus aureus and Streptococcus agalactiae
}

\author{
C. J. Foret, ${ }^{\star}$ W. E. Owens, † R. L. Boddie,† and P. Janowicz* \\ *West Agro Inc., Kansas City, MO 64153 \\ †Mastitis Research Laboratory, Hill Farm Research Station, \\ Louisiana State University Agricultural Center, Homer 71040
}

\section{ABSTRACT}

An experimental challenge trial was performed against Staphylococcus aureus and Streptococcus agalactiae following the procedures recommended by the National Mastitis Council. The efficacy of two teat dips, product 1 (Bovadine with I-Tech II) and product 2 (Bovadine with I-Tech, used as a positive control), was determined. Both teat dips contain 1\% iodine and $10 \%$ glycerin. Product 1 established an $89.7 \%$ reduction in infections against Staph. aureus and $73.1 \%$ reduction in infections against Strep. agalactiae. Product $2 \mathrm{dem}$ onstrated an $86.2 \%$ reduction in infections against Staph. aureus and $78.4 \%$ reduction in infections against Strep. agalactiae. Teat skin and teat ends were evaluated before and after the trial. No significant change in teat condition was observed for either product.

(Key words: iodine, Staphylococcus aureus, Streptococcus agalactiae, teat dip)

Abbreviation key: TSA = trypticase soy agar, TSB = trypticase soy broth.

\section{INTRODUCTION}

The efficacy of iodine teat dips depends not only on the concentration of iodine but also on other properties of the product. The purpose of this study was to test a new iodine teat dip that is based on I-Tech2 iodine technology US patent 5,916,581 (Foret, 1999) and to compare the performance to a control iodine product based on earlier technology. Both products tested incorporate the technology described in US patents 4,271,149 (Winicov et al., 1981) and 5,368,868 (Winicov, 1994).

In vitro testing was performed on both products under AOAC conditions at $4^{\circ} \mathrm{C}$. The in vitro tests were performed by Udder Health Systems, Inc., Bellingham, Washington, according to AOAC (1990) specifications, except that temperature was adjusted to $4^{\circ} \mathrm{C}$.

Received April 7, 2003.

Accepted June 7, 2003.

Corresponding author: C. Foret; e-mail: chris.foret@DeLaval.com.
Both products demonstrated excellent kill of Staphylococcus aureus at temperatures of 20 to $25^{\circ} \mathrm{C}$. However, the in vitro test results given in Table 1 show that product 1 was able to kill Staph. aureus more rapidly at low temperatures.

Both products were tested using the general procedures of the experimental challenge protocol recommended by the National Mastitis Council. The experimental challenge trial was performed during moderate temperature conditions (average 72 to $80^{\circ} \mathrm{F}$ ) to confirm that both products performed acceptably under typical conditions.

The Hill Farm Research Station dairy herd of 96 cows was used in a controlled infection trial to determine the efficacy of two iodine teat dips for preventing IMI with Staph. aureus and Streptococcus agalactiae.

\section{MATERIALS AND METHODS}

The herd was divided into two groups: Herd 1 (48 cows) was used to test product 1 and herd 2 (48 cows) was used to test product 2 .

Sampling schedule. The bacteriologic status of mammary quarters was determined at initiation of the trial by collecting and culturing duplicate milk samples. A third sample was collected from specific quarters and cultured when results from the first two samples differed.

Milk samples were collected and analyzed weekly during the trial. When either Staph. aureus or Strep. agalactiae was present for the first time in a previously uninfected quarter, a second sample was collected immediately and cultured. All quarters were eligible for new infections during the trial except 1) those infected with organisms of the same species as challenge organisms, and 2) those with deformed or abnormal teats. Fossomatic SCC were determined on one set of quarter milk samples collected at the initiation of the trial and monthly thereafter.

Collection of milk samples. Before sampling, two or three streams of foremilk were discarded. Each teat apex was scrubbed for several seconds with a cotton pledget moistened with $70 \%$ alcohol. Teats on the oppo- 
Table 1. Association of Official Analytical Chemists in vitro tests performed at $4^{\circ} \mathrm{C}$ against Staphylococcus aureus without milk challenge.

\begin{tabular}{lll}
\hline \multirow{2}{*}{$\begin{array}{l}\text { Exposure } \\
\text { time }\end{array}$} & \multicolumn{2}{c}{ Log reduction of Staph. aureus } \\
\cline { 2 - 3 } (s) & Product 1 & Product 2 \\
\hline 5 & 3.7 & $<3.49$ \\
15 & 4.09 & $<3.49$ \\
30 & 7.89 & $<3.49$ \\
\hline
\end{tabular}

site side of the udder from the technician were sanitized first, and milk samples were collected in reverse order in sterile, snap-cap plastic tubes and refrigerated at $5^{\circ} \mathrm{C}$.

Laboratory culture procedures. Samples were mixed by shaking, and a $0.01-\mathrm{ml}$ aliquot was streaked on trypticase soy agar (TSA) containing $5 \%$ bovine blood. Plates were incubated at $37^{\circ} \mathrm{C}$ for $48 \mathrm{~h}$ and examined to identify microorganisms present. An IMI was confirmed when: 1) Staph. aureus or Strep. agalactiae was isolated from a clinical quarter, 2) two consecutive samples yielded 500 or more $\mathrm{cfu} / \mathrm{ml}$ of the same pathogen, or 3) three consecutive samples contained 100 to $400 \mathrm{cfu} / \mathrm{ml}$ of the same pathogen.

Treatment method. At the afternoon milking, Monday through Friday, the lower third of all four teats of each cow was experimentally exposed to a challenge suspension containing both Staph. aureus (Newbould 305) and Strep. agalactiae (McDonald 44) immediately after milking. Within 5 to $10 \mathrm{~s}$ thereafter, two teats (left front, right rear) were dipped full length with teat dip; the remaining two teats served as undipped controls. Teats were exposed to challenge organisms to increase the number of pathogens impinging on the teat apex, resulting in an increased rate of IMI.

Preparation of challenge suspensions. Stock suspensions of Staph. aureus (Newbould 305) were prepared weekly. The contents of one lyophilized vial of Staph. aureus were reconstituted in $6 \mathrm{ml}$ of trypticase soy broth (TSB) and incubated at $37^{\circ} \mathrm{C}$ for 5 to $7 \mathrm{~h}$. This culture was used to inoculate $500 \mathrm{ml}$ of TSB, which was incubated on a gyratory shaker for $16 \mathrm{~h}$. After incubation, bacterial cells were pelleted by centrifugation, washed twice with $0.1 \%$ proteose-peptone, and resuspended to the original volume in proteose-peptone. Serial dilutions were made in proteose-peptone, and 0.1 $\mathrm{ml}$ was plated on TSA. Plates were incubated for $24 \mathrm{~h}$ at $37^{\circ} \mathrm{C}$, and colonies were counted to ascertain the microbial concentration of the stock suspension. This suspension was stored at $5^{\circ} \mathrm{C}$ and used daily for $1 \mathrm{wk}$ to prepare challenge suspensions of Staph. aureus (Hogan et al., 1990).

Streptococcus agalactiae (McDonald 44) cultures were prepared by thawing a frozen vial of Strep. agalac- tiae, and a 0.01-ml aliquot was streak plated onto each of five TSA plates. Plates were incubated at $37^{\circ} \mathrm{C}$ for $16 \mathrm{~h}$ and stored at $5^{\circ} \mathrm{C}$ to serve as stock cultures for a 1-wk period.

Daily challenge suspensions of Strep. agalactiae were prepared by inoculating $6-\mathrm{ml}$ tubes of TSB with six colonies from a TSA stock plate. The 6 -ml cultures were incubated for $7 \mathrm{~h}$ at $37^{\circ} \mathrm{C}$. A $500-\mathrm{ml}$ flask of TSB was inoculated with the 6-ml cultures and incubated for approximately $18 \mathrm{~h}$ at $37^{\circ} \mathrm{C}$ on a gyratory shaker. Specific aliquots of the culture were added to pasteurized milk as needed to adjust the concentration of Strep. agalactiae to approximately $5 \times 10^{7} \mathrm{cfu} / \mathrm{ml}$.

An aliquot of the Staph. aureus stock suspension was added to the Strep. agalactiae suspension to obtain a concentration of approximately $5 \times 10^{7} \mathrm{cfu} / \mathrm{ml}$ of Staph. aureus. This bacterial suspension was taken immediately to the milking parlor to challenge teats during the afternoon milking. A plate count was conducted daily on challenge suspensions and recorded.

Statistical methods. The Student $t$ test was used to evaluate the statistical difference between the dipped and control quarter data. This procedure was described by Hogan et al. (1990). The statistical probability of difference in IMI between the control and dipped quarters is measured from the value of $t . t=\left[\left(x_{1} / n_{1}\right)-\left(x_{2}\right)\right.$

Table 2. Average teat skin condition and teat end condition scores before and at the end of the trial.

\begin{tabular}{lll}
\hline & $\begin{array}{l}\text { Start of } \\
\text { trial }\end{array}$ & $\begin{array}{l}\text { End of } \\
\text { trial }\end{array}$ \\
\hline $\begin{array}{l}\text { Product } 1 \text { skin }^{1} \\
\text { Dipped } \\
\text { Control }\end{array}$ & 1.00 & \\
$\begin{array}{l}\text { Product } 1 \text { end }^{2} \\
\text { Dipped }\end{array}$ & 1.00 & 1.00 \\
$\quad$ Control & 1.01 & 1.00 \\
$\begin{array}{l}\text { Product 2 } \text { skin }^{1} \\
\quad \text { Dipped }\end{array}$ & 1.01 & 1.02 \\
$\quad$ Control & 1.00 & 1.03 \\
$\begin{array}{l}\text { Product 2 end } \\
\quad \text { Dipped } \\
\text { Control }\end{array}$ & 1.00 & 1.00 \\
\hline
\end{tabular}

${ }^{1}$ For skin condition scores, 1 = Teat skin is smooth, free from scales, cracks or chapping; $2=$ teat skin shows some evidence of scaling; 3 $=$ teat skin is chapped. Some small warts may be present. $4=$ Teat skin is chapped and cracked. Redness, indicating inflammation is present. Numerous warts may be present. $5=$ Teat skin is severely damaged and ulcerative with scabs or open lesions. Large and/or numerous warts present, which interfere with teat end function.

${ }^{2}$ For teat end scores, 1 = Teat end sphincter is smooth with no evidence of irritation; 2 = teat end has a raised ring; 3 = teat end sphincter is roughened with slight cracks, but no redness is present; 4 $=$ teat end sphincter is inverted with many cracks, giving a "flowered" appearance. Teat end may have old but healing scabs. $5=$ Teat end is severely damaged and ulcerative with scabs or open lesions. Large and/or numerous warts present which interfere with teat end functions. 
Table 3. Summary of efficacy data for product $1^{1}$ against Staphylococcus aureus and Streptococcus agalactiae.

\begin{tabular}{|c|c|c|c|c|c|c|c|c|c|c|c|c|}
\hline \multirow{3}{*}{$\begin{array}{l}\text { Organism } \\
\text { and } \\
\text { treatment }\end{array}$} & \multirow{3}{*}{$\begin{array}{l}\text { Quarters } \\
\text { eligible for } \\
\text { new IMI }\end{array}$} & \multicolumn{11}{|c|}{ New IMI } \\
\hline & & \multicolumn{8}{|c|}{ Week } & \multirow{2}{*}{$\begin{array}{l}\text { Quarter } \\
\text { days at risk } \\
\text { for new IMI }\end{array}$} & \multirow{2}{*}{$\begin{array}{l}\text { Quarters } \\
\text { infected } \\
(\%)\end{array}$} & \multirow{2}{*}{$\begin{array}{l}\text { Reduction } \\
(\%)\end{array}$} \\
\hline & & 1 & 2 & 3 & 4 & 5 & 6 & 7 & Total & & & \\
\hline \multicolumn{13}{|c|}{ Staph. aureus } \\
\hline Dip & 92 & 0 & 0 & 1 & 0 & 0 & 0 & 1 & 2 & 4203 & 2.2 & \\
\hline Control & 89 & 3 & 4 & 4 & 3 & 0 & 2 & 2 & 18 & 3894 & 20.2 & $89.7^{*}$ \\
\hline \multicolumn{13}{|c|}{ Strep. agalactiae } \\
\hline Dip & 92 & 3 & 0 & 0 & 1 & 0 & 0 & 2 & 6 & 4751 & 6.5 & \\
\hline Control & 92 & 7 & 3 & 4 & 0 & 0 & 4 & 2 & 20 & 4263 & 21.7 & $73.1^{* *}$ \\
\hline
\end{tabular}

$\left.\left.\mathrm{n}_{2}\right)\right] /\left[\left(\mathrm{x}_{1}+\mathrm{x}_{2}\right) /\left(\mathrm{n}_{1} \mathrm{n}_{2}\right)\right]^{0.5}$, where: $\mathrm{x}_{1}=$ number of new IMI in control quarters, $x_{2}=$ number of new IMI in treated quarters, $\mathrm{n}_{1}=$ (number of control quarters)(days of exposure), $\mathrm{n}_{2}=$ (number of treated quarters)(days of exposure); \% Reduction $=100\left[\left(\mathrm{x}_{1} / \mathrm{n}_{1}\right)-\left(\mathrm{x}_{2} / \mathrm{n}_{2}\right)\right] /\left(\mathrm{x}_{1} / \mathrm{n}_{1}\right)$. A teat dip is considered efficacious if the percentage of reduction is at least $40 \%$.

Scoring of teat condition. Characteristics of teat end and teat skin condition in dipped and control teats were scored immediately before the trial was initiated and at the conclusion of the trial to determine any effects of the teat dip products on the condition of teat ends and lateral teat skin. An ordinal scale of 1 to 5 was used. (See specifications of ordinal scale in Table 2).

Product description. The teat dips were provided ready to use from West Agro Inc. Kansas City, Missouri. Product 1 (Bovadine with I-Tech II) and product 2 (used as a positive control, see Eberhart et al. 1983) (Bovadine with I-Tech) contain $1 \%$ available iodine and $10 \%$ glycerin. The I-Tech II technology is described in US patent 5,916,581, and I-Tech technology is described in US patent $4,271,149$. Both products 1 and 2 also comply with US patent 5,368,868.

\section{RESULTS}

Infection data collected during the trial are summarized in Tables 3 and 4 . In herd 1 , in which product 1 was tested, a total of 20 new Staph. aureus IMI were confirmed: 18 in control quarters and two in dipped quarters (Table 3). Twenty-six new Strep. agalactiae IMI were confirmed: 20 in control quarters and six in dipped quarters (Table 3). The teat dip reduced the infection rate $89.7 \%$ for Staph. aureus $(P<0.001)$ and $73.1 \%$ for Strep. agalactiae $(P<0.005)$.

In herd 2 , in which product 2 was tested, a total of 22 new Staph. aureus IMI were confirmed: 19 in control quarters and three in dipped quarters (Table 4). Twenty-one new Strep. agalactiae IMI were confirmed: 17 in control quarters and four in dipped quarters (Table 4). This group was dipped for an extra week with S. agalactiae in an effort to increase the total number of Strep. agalactiae infections. The teat dip reduced the infection rate for Staph. aureus $86.2 \%(P<0.001)$ and $78.4 \%$ for Strep. agalactiae $(P<0.005)$.

Teats in both dip groups were scored for chapping, cracks, and other forms of irritation, both before and

Table 4. Summary of efficacy data for product $2^{1}$ against Staphylococcus aureus and Streptococcus agalactiae.

\begin{tabular}{|c|c|c|c|c|c|c|c|c|c|c|c|c|c|}
\hline \multirow{3}{*}{$\begin{array}{l}\text { Organism } \\
\text { and } \\
\text { treatment }\end{array}$} & \multirow{3}{*}{$\begin{array}{l}\text { Quarters } \\
\text { eligible for } \\
\text { new IMI }\end{array}$} & \multicolumn{12}{|c|}{ New IMI } \\
\hline & & \multicolumn{9}{|c|}{ Week } & \multirow{2}{*}{$\begin{array}{l}\text { Quarter } \\
\text { days at risk } \\
\text { for new IMI }\end{array}$} & \multirow{2}{*}{$\begin{array}{l}\text { Quarters } \\
\text { infected } \\
(\%)\end{array}$} & \multirow{2}{*}{$\begin{array}{l}\text { Reduction } \\
(\%)\end{array}$} \\
\hline & & 1 & 2 & 3 & 4 & 5 & 6 & 7 & 8 & Total & & & \\
\hline \multicolumn{14}{|c|}{ Staph. aureus } \\
\hline Dip & 89 & 2 & 0 & 1 & 0 & 0 & 0 & 0 & & 3 & 4252 & 3.4 & \\
\hline Control & 89 & 6 & 4 & 3 & 3 & 2 & 1 & 0 & & 19 & 3706 & 21.3 & $86.2^{*}$ \\
\hline \multicolumn{14}{|c|}{ Strep. agalactiae } \\
\hline Dip & 92 & 1 & 0 & 0 & 0 & 1 & 1 & 1 & 0 & 4 & 4955 & 4.3 & \\
\hline Control & 92 & 7 & 1 & 0 & 1 & 2 & 4 & 2 & 0 & 17 & 4555 & 18.5 & $78.4^{* *}$ \\
\hline
\end{tabular}


at the end of the trial. There were no changes in teat end or teat skin characteristics during the trial. In addition, any teat irritation or abnormalities could not be attributed to use of either teat dip product. The average condition scores are listed in Table 2.

\section{CONCLUSIONS}

Both iodine teat dips significantly reduced the new IMI caused by Staph. aureus by 89.7 and $86.2 \%$. Both products also significantly reduced new IMI caused by Strep. agalactiae by 73.1 and $78.4 \%$. Teat condition remained very good from the start to the end of the trial. These results confirm both products perform well under moderate temperature conditions. As implied from the in vitro data, additional trials performed under low temperature conditions may show efficacy differences.

\section{REFERENCES}

Association of Official Analytical Chemists. 1990. Official Methods of Analysis. Pages 138-140 in Germicidal and Detergent Sanitizing Action of Disinfectants, Vol. I. 15th ed. AOAC, Arlington, VA.

Eberhart, R. J., P. L. LeVan, L. C. Griel, Jr., and E. M. Kesler. 1983. Germicidal teat dip in a herd with low prevalence of Streptococcus agalactiae and Staphylococcus aureus mastitis. J. Dairy Sci. 66:1390-1395.

Foret, C., and T. C. Hemling. 1999. Iodine Antimicrobial Compositions Containing Nonionic Surfactants and Halogen Anions. West Agro Inc. U. S. PAT 5,916,581. A01N 25/02.

Hogan, J. S., D. M. Galton, R. J. Harmon, S. C. Nickerson, S. P. Oliver, and J. W. Pankey. 1990. Protocols for evaluating efficacy of postmilking teat dips. J. Dairy Sci. 73:2580-2585.

Winicov, M. W. 1994. West Agro Inc. U. S. PAT 5,368,868. A01N 59/ 12. Winicov, M. W., N. Y. Woodside, and M. Oberlander. 1981. West Agro Inc. U. S. PAT 4,271,149. A01N 59/12. 